\title{
Culturable bacterial strains isolated from Bemisia tabaci (Gennadius, 1889) (Hemiptera: Aleyrodidae) populations of Adana and Mersin Provinces of Turkey and their entomopathogen characteristics ${ }^{1}$
}

\author{
Türkiye'nin Adana ve Mersin illerinden toplanan Bemisia tabaci (Gennadius, 1889) \\ (Hemiptera: Aleyrodidae) popülasyonlarıyla ilişkili kültüre alınabilen bakteriler ve \\ entomopatojen özelliklerinin belirlenmesi
}

\section{Şebnem TíRENG KARUT ${ }^{2} \quad$ Kamil KARUT $^{3} \quad$ Yeşim AYSAN $^{3}$}

\begin{abstract}
Whitefly, Bemisia tabaci (Gennadius, 1889) (Hemiptera: Aleyrodidae) hosting various bacteria is among the most significant insect pest causing economic losses in agricultural production. A study was conducted to determine the bacterial flora of $B$. tabaci and to identify the efficiency of these bacteria against $B$. tabaci. Samples were collected from sesame and melon plants in Mersin and Adana Provinces of Turkey in 2014. Nine bacterial strains were identified by morphological, MALDI-TOF MS and molecular identification methods to species level. Bacillus sp., Methylobacterium sp., Microbacterium sp., Serratia marcescens and Sphingomonas sp. were identified from the samples collected from sesame and Acinetobacter Iwoffii, Bacillus cereus, Staphylococcus hominis and Staphylococcus warneri were identified from the samples collected from melon. To determine biological efficiency against $B$. tabaci adult (biotype B), whiteflies were fed with insect food as control (sucrose + water), insecticidal control (acetamiprid) and bacterial suspensions. The entomopathogenic bacteria S. marcescens isolated from B. tabaci for the first time in this study yielded an efficiency of $72 \%$ against adult whitefly. However, the other strains had efficiencies below $25 \%$. It was concluded, given the efficiency of $S$. marcescens, that further research should be conducted on the pathology of entomopathogenic bacteria in pest insects.
\end{abstract}

Keywords: Bemisia tabaci, biological control, entomopathogen bacteria, Serratia marcescens, symbiont

\section{Öz}

Bünyesinde çeşitli bakterileri barındıran, Beyazsinek, Bemisia tabaci (Gennadius, 1889) (Hemiptera: Aleyrodidae) tarımsal üretimlerde ekonomik kayıplara neden olan en önemli zararlı böcek türlerinden birisidir. Bu çalışmada B. tabacinnin bakteriyel florasını belirlemek ve bu bakterilerin etkinliğini ortaya çıkarmak amacıyla 2014 yılında iki farklı ilden (Mersin ve Adana) sırasıyla susam ve kavun bitkilerinden örnekler toplanmıştır. Morfolojik, MALDITOF MS ve moleküler tanı yöntemleri kullanılarak yapılan analizler sonucunda toplam 9 adet bakteri türü saptanmıştır. Susam tarlasından toplanan örneklerden Bacillus sp., Methylobacterium sp., Microbacterium sp., Serratia marcescens, Sphingomonas sp.; kavun bitkisinden toplanan örneklerden Acinetobacter Iwoffii, Bacillus cereus, Staphylococcus hominis ve Staphylococcus warneri türleri belirlenmiştir. Bemisia tabaci erginlerine (B biyotip) karşı yapılan biyolojik etkinlik çalışmalarında beyazsinekler, kontrol olarak böcek besini (sakkaroz+su), ilaçlı kontrol (acetamiprid) ve bakteri süspansiyonlarıyla beslenmişlerdir. İlk defa bu çalışma kapsamında $B$. tabaciden izole edilen ve entomopatojen bir bakteri olan $S$. marcescens ergin beyazsineğe karşı \%72 oranında başarılı olmuştur. Diğer izolatların etki oranları \%25'in altında kalmıştır. Serratia marcescens ile elde edilen bu başarı, izolatın zararlı böcekler üzerindeki patolojisi ile ilgili çalışmaların devam ettirilmesi gerektiği sonucunu ortaya çıkarmıştır.

Anahtar sözcükler: Bemisia tabaci, biyolojik mücadele, entomopatojen bakteri, Serratia marcescens, simbiyont

\footnotetext{
${ }^{1}$ Part of this work was presented as a poster presentation at the VII. Plant Protection Congress of Turkey (14-17 November 2018, Muğla, Turkey).

2 Biological Control Research Institute, 01321, Adana, Turkey

${ }^{3}$ Cukurova University, Faculty of Agriculture, Department of Plant Protection, 01330, Adana, Turkey

* Corresponding author (Sorumlu yazar) e-mail: sebnem.tirengkarut@tarimorman.gov.tr

Received (Alınış): 16.06.2019 Accepted (Kabul ediliş): 18.10.2019 Published Online (Çevrimiçi Yayın Tarihi): 10.12 .2019
} 


\section{Introduction}

As is common worldwide, cotton whitefly, Bemisia tabaci (Gennadius, 1889) (Hemiptera: Aleyrodidae) feeds on different host plants causing significant economic losses in Turkey. Adult and larval stages of the pest damage plants through sap-sucking, inducing sooty mold by secreting large amounts of honeydew and transmitting important plant viruses. Together with the development of transportation technologies and increasing international plant transfers, the pest has a global distribution and is encountered on every continent of the world, except for Antarctica. Bemisia tabaci is defined as a speciescomplex composed of at least 40 biotypes. Among the biotypes, B (Bemisia argentifolii Bellows \& Perring, 1994, and MEAM1 = Middle East Asia Minor 1) and Q (MED = Mediterranean) are the most common and invasive. Given the high biotic potential and rapid increase in population size, these biotypes are able to generate economic losses in a short time, consequently chemical control is the most preferred. However, with the use of chemicals, resistant biotypes have become widespread and result in epidemic disease outbreaks generating significant economic losses in Turkey and globally (Henneberry \& Faust, 2008; Karut et al., 2017). Bemisia biotypes develop resistance to insecticides over time, thus integrated pest control including biopesticides and biological control is required for the long-term management of this pest (Ateyyat et al., 2009).

Microorganisms are colonized insects forming films over of the cuticle and intestines, and also form microbial populations in the hemocoel, body fluids and cells (Jing et al., 2014). Bacteria in their host insects are important for food digestion, pheromone synthesis, $\mathrm{pH}$ regulation, vitamin and amino acid synthesis, resistance development against parasitoids and entomopathogens (Dillon \& Dillon, 2004; Ateyyat et al., 2010; Zhang et al., 2014). So, bacteria can be symbionts essential for survival of the insect but also entomopathogens that kill them.

Some insects of the Sternorrhyncha suborder of Hemiptera (psyllids, whiteflies, aphids and mealybugs) are in obligate-relationship with primary and secondary endosymbiont bacteria. The individuals of this suborder with piercing-sucking mouthparts in $B$. tabaci complex have seven different bacterial species carried on their body. These are Portiera aleyrodidarum (obligate primary endosymbiont), Arsenophonus, Hamiltonella, Rickettsia, Wolbachia, Cardinium and Fritschea (facultative secondary endosymbionts) all of which evolved with Aleyrodidae species. These bacteria either negatively or positively influence vital activities of the insect (Thao \& Baumann, 2004).

Majority of entomopathogenic bacteria infect insects through their digestive system. Those living over the surface may penetrate into the body through wounds. In contrast to fungal entomopathogens, bacterial entomopathogens are not able to actively penetrate into outer integument of the insect (Demirbag et al., 2008). The majority of the bacteria obtained from whiteflies form mutual interactions with the insects contributing to digestion and nutrition of the host. These bacteria can occur in intestines of the whitefly and associated sooty mold (Davidson et al., 2000). Although some of these bacteria associated with whitefly were found to be promising in biological efficiency studies, studies on the use of bacteria in biological control of the piercing-sucking mouthparts insects are ongoing (Ateyyat et al., 2009; Roopa et al., 2014).

Demonstration of the interaction between $B$. tabaci and its bacterial entomopathogens and symbionts has a significant potential for developing control practices for the pest. Therefore, there is a need for detailed studies on bacteria-insect interactions and defense mechanisms of whitefly (Zhang et al., 2014). In this study, culturable bacterial strains were isolated from the flora of $B$. tabaci to determine their potential entomopathogenic properties for biological control of the pest. Efficiency of the bacterial stains on whitefly was determined under laboratory conditions. 


\section{Materials and Methods}

\section{Bemisia tabaci populations}

To determine bacterial flora of whitefly, $B$. tabaci infected leaf samples and adult whitefly samples were collected from sesame and melon plants in Tarsus (Mersin Province) and Balcalı (Adana Province), respectively, in 2014. Adults were sampled directly from the plants with a mouth-aspirator to obtain at least 100 insects from each population.

\section{Bacterial isolations}

Adult and immature whiteflies were brought to laboratory and bacterial isolations were performed. About 100 pupae and 150 nymphs collected from the lower part of the leaves with a thin-pin insect needle in the laboratory and 100 adults collected from the field were surface sterilized with alcohol. These individuals were then separately crushed in nutrient broth and the suspension diluted to $1 \mathrm{ml}$ to generate stock suspensions. A dilution series of each suspension were prepared, and $100 \mu \mathrm{l}$ from each dilution was spread on nutrient agar (NA) with a glass rod and incubated at $25^{\circ} \mathrm{C}$. Bacterial isolates were subcultured on NA, yeast extract agar (YEA) and potato dextrose agar (PDA).

\section{Morphological and physiological tests}

Morphological and physiological identification of the bacterial strains were performed on NA, SNA (NA+5\% sucrose), King's B (KB) medium and yeast dextrose calcium carbonate agar (YDCA), gram reactions by potassium hydroxide and fluorescent pigmentation on $\mathrm{KB}$, and oxidase reaction (Lelliott \& Stead, 1987). All these tests were performed at Dr. Hatice Satar, Entomopathogen Laboratory of Adana Biological Control Research Institute, Turkey.

\section{MALDI-TOF MS identification}

MALDI-TOF MS (matrix-assisted laser desorption ionization-time of flight mass spectrometry) was used for identification of bacterial strains to genus and/or species level (Wunschel et al., 2005). This was done by a commercial service under the supervision of Prof. Dr. Soner Soylu from Mustafa Kemal University Plant Health and Clinics Research and Implementation Center (Antakya, Turkey).

\section{Molecular identification}

Strains not identified by MALDI-TOF MS were identified by molecular methods. For this purpose, DNA isolation was performed by the Dellaporta DNA extraction method (Dellaporta et al., 1983). Genomic DNA was amplified by PCR with 27F (5'-AGAGTTTGATCMTGGCTCAG-3') and 1492R (5'-TACGGYTAC CTTGTTACGACTT-3') primers for the $16 \mathrm{~S}$ region. Sequences of $\sim 1500 \mathrm{bp}$ PCR products were determined (Lane, 1991). The DNA sequences were arranged with the aid of Bioedit Software Version 7.2.5, then subjected to BLAST analysis (National Center for Biotechnology Information).

\section{Bioassays}

Biological efficiency of the bacteria against the lab population of $B$. tabaci biotype $B$ adult stage was determined through the modified method of Davidson et al. (2000). In this method, $2 \mathrm{ml}$ Eppendorf tubes were used to feed $B$. tabaci adults. Initially, the bottom of the tubes was cut with a bistoury and covered with $5 \mathrm{~cm}^{2}$ Parafilm pieces. The cut and Parafilm-covered section were covered again with Parafilm to give a $5 \mathrm{~mm}$ thick layer. Finally, the prepared tube was surrounded with duct tape (Davidson et al., 2000; Zhang et al., 2014). Twenty adults (1-2 d old) were then transferred to each tube. To have adult individuals of the same age, the plants with high populations of the pest at pupal stage were selected $2 \mathrm{~d}$ before the experiments and all adults were removed. These plants were then placed into Plexiglas cages to obtain newly hatched adults of the same age. The adults on the sides of the cages were used in experiments 
because their stylets would not be damaged. After transfer of adults, the tubes were placed upside-down into the cuvettes with Parafilm-covered section upward. Then, Parafilm-covered section was supplemented with $100 \mu \mathrm{l}$ of only insect food (negative control), insecticide with acetamiprid active ingredient (positive control) or suspensions of the bacterial strains. The insect food was prepared by smashing four discs of cotton leaf ( $15 \mathrm{~mm}$ diameter) in $100 \mathrm{ml}$ distilled water and $30 \mathrm{~g}$ sucrose. The positive control was prepared by supplementing insect food with $0.6 \mathrm{~g} / \mathrm{l}$ of an insecticide with acetamiprid active ingredient, commercially available and registered for whitefly. For bacterial suspensions, the bacteria developed in NA was collected with a loop and supplemented to $10 \mathrm{ml}$ of insect food. The suspension optical density was adjusted to 0.5 at $600 \mathrm{~nm}$ using a spectrophotometer.

Experiments were conducted with at least five replicates. Each feeding tube was regarded as a replicate. Counting was performed $48 \mathrm{~h}$ after commencing the experiments. The individuals that had fallen to the bottom of the tube and with no evident motion were accepted as dead.

\section{Statistical analysis}

In bioassay studies, mortality ratio (\%) of bacterial isolates was calculated as the ratio of dead individuals to total number of individuals. Percent values were subjected to arcsine square root transformation before the analysis. Normality of variances was checked using Levene's test. Analysis of variance (ANOVA) followed by Tukey's multiple range test at $5 \%$ significance level to determine differences between the means, for parametric data in SPSS (Version 23) software. Also, the percent efficiency of the isolates was calculated with the Henderson-Tilton equation (Karman, 1971).

\section{Results}

\section{Bacterial flora of Bemisia tabaci}

The strains obtained from $B$. tabaci samples collected from sesame were analyzed by MALDI-TOF MS and identified as Bacillus sp. (Bacillales: Bacillaceae), Methylobacterium sp. (Rhizobiales: Methylobacteriaceae), Microbacterium sp. (Actinomycetales: Microbacteriaceae) and Serratia marcescens (Enterobacteriales: Yersiniaceae); the strains obtained from the B. tabaci samples collected from melon were identified as Acinetobacter Iwoffii (Pseudomonadales: Moraxellaceae), Bacillus cereus (Bacillales: Bacillaceae), Staphylococcus hominis and S. warneri (Bacillales: Staphylococcaceae). Also, a strain obtained from whiteflies collected from sesame was compared with the data in system library for MALDITOF MS, but it was not able to be identified. Molecular methods were used for this bacterial strain and it was 99\% similar with Sphingomonas sp. (Sphingomonadales: Sphingomonadaceae).

Morphological examination revealed that Acinetobacter Iwoffii formed cream, smooth circular colonies on four different growth media. Bacillus cereus developed matt cream, circular colonies on all growth media and colonies had rough and wavy contours on YDCA and KB media. Bacillus sp. strain initially exhibited colorless colonies on all growth media, then turned cream-color on all media, except for YDCA on which it was yellow. This strain formed smooth circular colonies on all media, but had wavy contours on KB medium. Methylobacterium sp. strains exhibited quite slow development on all media and formed small circular colonies. The colonies were initially cream-color, then turned into light pink. Microbacterium sp. strains formed bright orange, smooth circular colonies on all media, but had a slightly bulbous texture on KB medium. Serratia marcescens strains formed red, smooth circular colonies on all growth media, but were light pink on SNA medium. These strains had bulbous development on NA and SNA, but were more bouffant on the other media. Sphingomonas sp. formed bright yellow, circular bulbous colonies in all media. Staphylococcus hominis and S. warneri strains developed in cream colonies on YDCA medium and close to white circular bulbous colonies on the other media (Table 1). 
Acinetobacter Iwoffii, S. marcescens and Sphingomonas sp. strains were gram-negative and the others as gram-positive. Bacillus cereus, Methylobacterium sp. and Sphingomonas sp. strains were oxidase-positive and all others oxidase-negative. None of the strains were fluorescent (Table 1).

Table 1. Culturable bacterial species isolated from Bemisia tabaci and morphological and physiological characteristics of the strains

\begin{tabular}{|c|c|c|c|c|c|c|c|}
\hline \multirow[b]{2}{*}{ Species } & \multicolumn{4}{|c|}{ Colony development in growth media } & \multicolumn{3}{|c|}{ Reactions } \\
\hline & $N A^{*}$ & SNA & $\mathrm{KB}$ & YDCA & $\begin{array}{c}\text { Gram } \\
\text { reaction }\end{array}$ & Oxidase & $\mathrm{F} / \mathrm{NF}$ \\
\hline Acinetobacter Iwoffii & $\begin{array}{l}\text { Cream, circular, } \\
\text { smooth }\end{array}$ & $\begin{array}{l}\text { Cream, circular, } \\
\text { smooth }\end{array}$ & $\begin{array}{l}\text { Cream, circular, } \\
\text { smooth }\end{array}$ & $\begin{array}{l}\text { Cream, circular, } \\
\text { smooth }\end{array}$ & - & - & NF \\
\hline Bacillus cereus & $\begin{array}{l}\text { Matt cream, } \\
\text { circular }\end{array}$ & $\begin{array}{l}\text { Matt cream, } \\
\text { circular }\end{array}$ & $\begin{array}{l}\text { Matt cream, circular, } \\
\text { wavy contours }\end{array}$ & $\begin{array}{l}\text { Matt cream, circular, } \\
\text { wavy contours }\end{array}$ & + & + & NF \\
\hline Bacillus sp. & $\begin{array}{l}\text { Cream, circular, } \\
\text { smooth }\end{array}$ & $\begin{array}{l}\text { Cream, circular, } \\
\text { smooth }\end{array}$ & $\begin{array}{l}\text { Cream, circular, } \\
\text { wavy contours }\end{array}$ & $\begin{array}{l}\text { Yellow, circular, } \\
\text { smooth }\end{array}$ & + & - & NF \\
\hline Methylobacterium sp. & $\begin{array}{l}\text { Light pink, } \\
\text { circular }\end{array}$ & $\begin{array}{l}\text { Light pink, } \\
\text { circular }\end{array}$ & Light pink, circular & Light pink, circular & + & + & NF \\
\hline Microbacterium sp. & $\begin{array}{l}\text { Orange, } \\
\text { circular, smooth }\end{array}$ & $\begin{array}{l}\text { Orange, } \\
\text { circular, smooth }\end{array}$ & $\begin{array}{l}\text { Orange, circular, } \\
\text { slightly bulbous }\end{array}$ & $\begin{array}{l}\text { Orange, circular, } \\
\text { smooth }\end{array}$ & + & - & NF \\
\hline Serratia marcescens & $\begin{array}{l}\text { Red, circular, } \\
\text { bulbous }\end{array}$ & $\begin{array}{l}\text { Light pink, } \\
\text { circular, bulbous }\end{array}$ & $\begin{array}{l}\text { Red, circular, } \\
\text { bouffant }\end{array}$ & $\begin{array}{l}\text { Red, circular, } \\
\text { bouffant }\end{array}$ & - & - & NF \\
\hline Sphingomonas sp. & $\begin{array}{l}\text { Yellow, circular, } \\
\text { bulbous }\end{array}$ & $\begin{array}{l}\text { Yellow, circular, } \\
\text { bulbous }\end{array}$ & $\begin{array}{l}\text { Yellow, circular, } \\
\text { bulbous }\end{array}$ & $\begin{array}{l}\text { Yellow, circular, } \\
\text { bulbous }\end{array}$ & - & + & NF \\
\hline Staphylococcus hominis & $\begin{array}{l}\text { White, circular, } \\
\text { bulbous }\end{array}$ & $\begin{array}{l}\text { White, circular, } \\
\text { bulbous }\end{array}$ & $\begin{array}{l}\text { White, circular, } \\
\text { bulbous }\end{array}$ & $\begin{array}{l}\text { Cream, circular, } \\
\text { bulbous }\end{array}$ & + & - & NF \\
\hline Staphylococcus warneri & $\begin{array}{l}\text { White, circular, } \\
\text { bulbous }\end{array}$ & $\begin{array}{l}\text { White, circular, } \\
\text { bulbous }\end{array}$ & $\begin{array}{l}\text { White, circular, } \\
\text { bulbous }\end{array}$ & $\begin{array}{l}\text { Cream, circular, } \\
\text { bulbous }\end{array}$ & + & - & NF \\
\hline
\end{tabular}

* NA, nutrient agar; SNA (NA+5\% sucrose); KB, King's B; YDCA, yeast dextrose calcium carbonate agar; F/NF, fluorescent/nonfluorescent).

\section{Biological efficiency of bacterial strains against Bemisia tabaci}

For biological efficiency of bacterial strains against $B$. tabaci adults, mortality and \% impact ratios were compared and analyzed accordingly. According to the ANOVA of data obtained $2 \mathrm{~d}$ after the treatment, the differences in mortality and \% impact ratios of the treatments were found to be significantly different from the control treatment $(\mathrm{df}=10, \mathrm{~F}=14.8, \mathrm{P}<0.005)($ Table 2$)$.

Mortality ratios are shown in Figure 1. After acetamiprid treatment, the greatest mortality ratios were observed in S. marcescens (75\%), Microbacterium sp. (31\%), S. warneri (29\%), Sphingomonas sp. (25\%), S. hominis $(23 \%)$ and $B$. cereus (24\%) strains. Mortality ratios of the other strains were all below $20 \%$.

The mortality ratios of the adults fed with bacterial strains suspensions and insect food (control) were compared and \% impact ratios were calculated with the Henderson-Tilton equation (Table 2). Impact ratios of the treatments varied between 9 and $91 \%$ and two treatments ( $A$. Iwoffii and Methylobacterium sp.) were found to be ineffective. The greatest impact ratio (91\%) was obtained from acetamiprid (positive control) treatment. The greatest impact ratio of the bacterial strains $(72 \%)$ was obtained from S. marcescens and this treatment was placed into the same group with the acetamiprid treatment. $S$. marcescens was followed by Microbacterium sp. (24\%) (Table 2). Additionally, there was a distinctive color change (reddening) in dead individuals fed with S. marcescens strain (Figure 2).

For mortality and impact ratios (\%) of the bacterial strains, only Serratia marcescens had an impact greater than $70 \%$ (Table 2, Figure 1). 
Culturable bacterial strains isolated from Bemisia tabaci (Gennadius, 1889) (Hemiptera: Aleyrodidae) populations of Adana and Mersin Provinces of Turkey and their entomopathogen characteristics

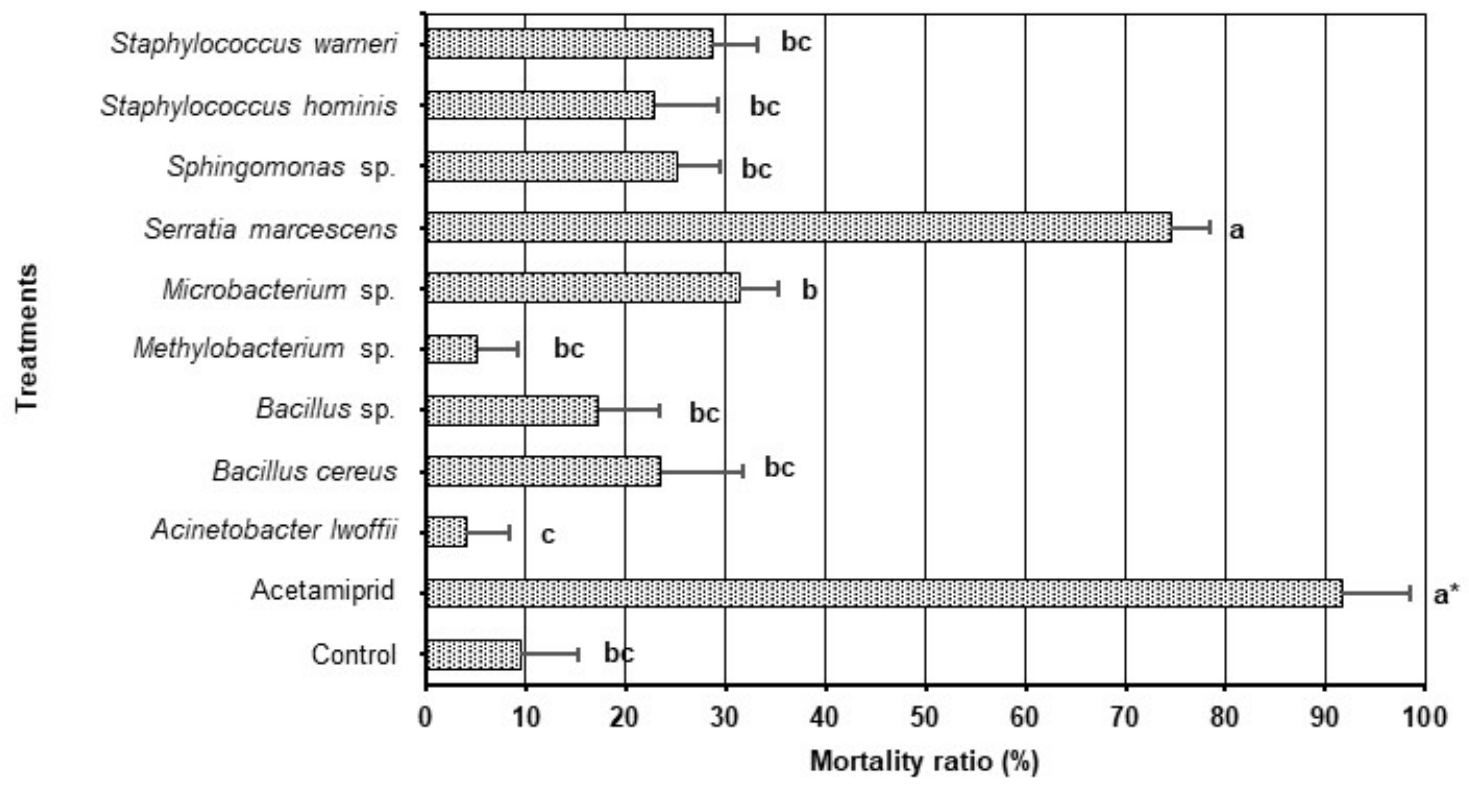

Figure 1. Mortality ratios of Bemisia tabaci adults with different bacterial strains treatments (\%).

* The means with the same latter is not different significantly by Tukey's Multiple Range Test $(P>0.005)$.

Table 2. Henderson-Tilton \% impact ratios of different bacterial strains applied against Bemisia tabaci adults

\begin{tabular}{lcccc}
\hline Treatments & $\mathrm{N}$ & Dead & Alive & Impact (\%) \\
\hline Control & 138 & 13 & 125 & \\
Acetamiprid & 107 & 98 & 9 & 91 \\
Acinetobacter lwoffii & 100 & 4 & 96 & 0 \\
Bacillus cereus & 102 & 24 & 78 & 16 \\
Bacillus sp. & 84 & 17 & 67 & 9 \\
Methylobacterium sp. & 116 & 6 & 110 & 0 \\
Microbacterium sp. & 131 & 41 & 90 & 24 \\
Serratia marcescens & 110 & 82 & 28 & 72 \\
Sphingomonas sp. & 103 & 26 & 77 & 17 \\
Staphylococcus hominis & 109 & 25 & 84 & 15 \\
Staphylococcus warneri & 129 & 37 & 92 & 21 \\
\hline
\end{tabular}

$\mathrm{N}$, total number of individuals; control, insect food; acetamiprid, positive control.
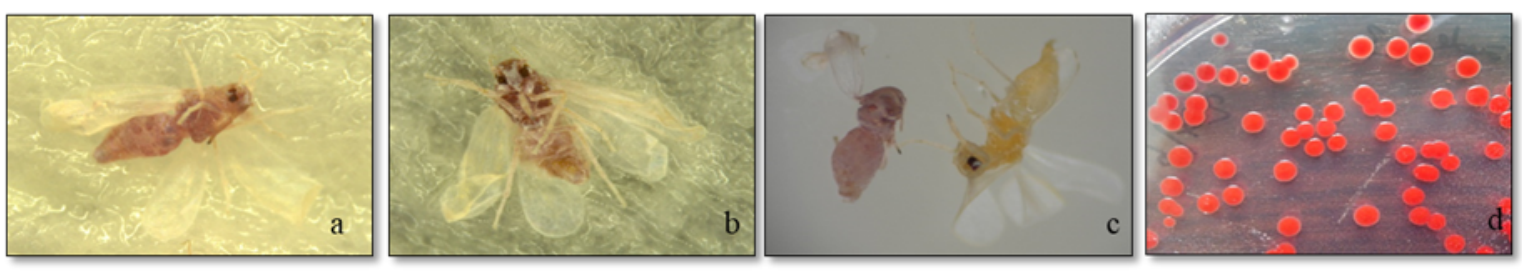

Figure 2. a, b) Adult Bemisia tabaci with color change after Serratia marcescens strain treatment, c) pathogen-infected and dead individuals in control, d) colony development of the pathogen in Nutrient agar medium. 


\section{Discussion}

Nine bacterial species were obtained from $B$. tabaci collected from sesame and melon plants. The strains obtained from $B$. tabaci samples collected from sesame were Bacillus sp., Methylobacterium sp., Microbacterium sp., S. marcescens and Sphingomonas sp., and the strains from melon were A. Iwoffii, $B$. cereus, S. hominis and $S$. warneri. In biological control of insects, bacteria are not as advantageous as fungi because bacteria are not able to penetrate into cuticle. Bacteria directly infect only through digestive system (Demirbag et al., 2008). Zhang et al. (2014) indicated two main approaches for bacterial infection of the insects, feeding and injection into hemocoel, and also indicated that feeding was preferred because it is more natural and does not generate any physical damages on the host. Therefore, the method recommended by Davidson et al. (2000) and Zhang et al. (2014) was used to determine biological efficiency of the bacteria and whiteflies were fed with bacterial suspensions for $48 \mathrm{~h}$.

Two bacterial strains, Bacillus sp. and $B$. cereus were isolated from the whiteflies collected from melon. El-Assal et al. (2013) conducted an efficiency study of $B$. cereus against $B$. tabaci, they isolated the bacteria from the soil and applied it to second instar nymphs and reported $18 \%$ mortality $10 \mathrm{~d}$ after application. Although this mortality was achieved against nymphs, it is consistent with the $16 \%$ mortality achieved against adult with $B$. cereus.

Microbacterium species interact with insects. Of these bacteria, Microbacterium testaceum and $M$. thalassium were isolated from Ostrinia nubilalis (Hübner, 1796) (Lepidoptera: Pyralidae) larvae, Microbacterium arborescens from Sesamia nonagrioides (Lefèbvre, 1827) (Lepidoptera: Noctuidae) and M. liquefaciens were isolated from Dendroctonus micans (Kugelann, 1794) (Coleoptera: Curculionidae) (Yaman et al., 2010; Secil et al., 2012; Eski et al., 2015). In the present study, Microbacterium sp. was isolated from whiteflies collected from sesame, but the efficiency (24\%) against $B$. tabaci was found to be low.

Bacteria of the genus Serratia are quite widespread in nature, but rare in humans and animals. The majority of those isolated from humans do not produce pigments, whereas those isolated from insects are generally pigmented (Sikorowski et al., 2001). Serratia marcescens, S. entomophila, S. odorifera, S. ureilytica, S. grimesii and S. liquefaciens are Serratia species isolated from the insects (Grimont et al., 1988; Sezen, 1998; Ince et al., 2008; Albayrak Iskender, 2009; Yaman et al., 2010; Sezen et al., 2013). Serratia marcescens, non-pathogenic at low-density, pass into hemocoel, multiply there and kill the insect in 1 to $3 \mathrm{~d}$ (Sikorowski et al., 2001). Serratia marcescens common in insects is commonly isolated from several pests of Lepidoptera and Coleoptera (Cakici et al., 2014; Eski et al., 2015; Pu \& Hou, 2016; Bidari et al., 2018). However, there are no records on the isolation of this bacteria from the whiteflies. Serratia marcescens was isolated for the first time in this study from $B$. tabaci collected from sesame yielded significant efficiency $(72 \%)$ against this host. Similarly, S. marcescens yielded efficiency of between 50 and $100 \%$ against agricultural pests like Rhynchites bacchus (L., 1758) (Coleoptera: Rhynchitidae), Polyphylla olivieri (Castelnau, 1840) (Coleoptera: Scarabaeidae), Oberea linearis (L., 1761). (Coleoptera: Cerambycidae), Balaninus nucum (L., 1758) (Coleoptera: Curculionidae), Rhynchophorus ferrugineus (Oliver, 1790) (Coleoptera: Curculionidae), S. nonagrioides, Spodoptera littoralis (Boisduval, 1833) (Lepidoptera: Noctuidae) and O. nubilalis (Sezen \& Demirbag, 1999; Bahar \& Demirbag, 2007; Gokce et al., 2009; Secil et al., 2012; Pu \& Hou, 2016).

Staphylococcus spp. are commonly isolated from various insect groups including whiteflies (Davidson et al., 2000; Yu et al., 2008; Ateyyat et al., 2010; Cakici et al., 2015; Pu \& Hou, 2016). Ateyyat et al. (2009) tested Staphylococcus gallinarum isolated from $B$. tabaci against the second instar nymphs of the pest through the leaf dipping method and reported that bacteria generated 19.5 and $28 \%$ infection after 3 and $5 \mathrm{~d}$, respectively. These researchers indicated that a toxin secreted by the bacteria might have acted as an antibiotic and this toxin resulted in death of the pest through destruction of the interactions between B. tabaci and its symbionts. Davidson et al. (2000) found Staphylococcus aureus and S. epidermidis 
isolated from $B$. argentifolii ineffective against the pest. These researchers indicated that bacteria either never or rarely enter into the esophagus and that bacteria should have a diameter of $0.5 \mu \mathrm{m}$ to pass through the stylet of a whitefly. In this study, S. hominis and $S$. warneri were isolated from $B$. tabaci from melon. Staphylococcus hominis and $S$. warneri isolates yielded efficiency of 15 and $21 \%$ against $B$. tabaci, respectively, which is similar to the results of Ateyyat et al. (2009).

In conclusion, in biological efficiency experiments conducted with the bacteria, only the $S$. marcescens strain provided an efficiency of greater than $70 \%$ in a short period $(2 \mathrm{~d})$ in feeding experiments, so this strain is considered to be a potential microbial control agent. Further research on the efficacy of entomopathogenic bacteria $S$. marcescens isolated from $B$. tabaci is needed as such research could make a great contribution to development of alternative methods to chemical control. Genetically-modified plants are now commonly used in pest control. Transgenic cotton, maize and potato plants producing Bacillus thuringiensis (Bt) toxins against pests are the best-known (Demirbag et al., 2008). While the plants producing Bt toxins are effective against the pests of Lepidoptera and Coleoptera insects with chewing mouthparts, they are not effective against the pests with piercing-sucking mouthparts. In the present study, S. marcescens yielded a high efficiency $(72 \%)$ against $B$. tabaci adults. With the aid of biotechnological methods, as with Bt toxin-producing plants, transgenic plants able to produce $S$. marcescens toxins could be developed. In this way, with a new generation transgenic plants, a successful biotechnological control method, could be developed against piercing-sucking mouthparts pests as well as those with chewing mouthparts. In addition, testing the activity of the $S$. marcescens strain in chewing mouthparts insects could also provide important information that would be useful to improve biological control.

\section{Acknowledgments}

This study presents partial results of a PhD project supported by Çukurova University Scientific Research Projects Department (FDK-2015-5239) and General Directorate of Agricultural Researches and Policies (TAGEM-BS-13/09-01/02-05). Thanks, is extended to Assoc. Prof. Dr. Zeki Gökalp for his support in preparation of this paper.

\section{References}

Albayrak Iskender, N., 2009. The Bacterial Flora of Dendroctonus micans (Kugelann 1974) and Ips typographus (Linne 1758) and the Determination of the Potential of the Members of These Flora as a Biocontrol Agent Against to Dendroctonus micans. Atatürk University Graduate School of Natural and Applied Sciences, Department of Biology, (Unpublished) PhD Thesis, Erzurum, 109 pp.

Ateyyat, M. A., M. Shatnawi \& M. S. Al-Mazra'awi, 2009. Culturable whitefly associated bacteria and their potential as biological control agents. Jordan Journal of Biological Sciences, 2: 139-144.

Ateyyat, M. A., M. Shatnawi \& M. Al-Mazra'awi, 2010. Isolation and identification of culturable forms of bacteria from the Sweet potato whitefly Bemisia tabaci Genn. (Homoptera: Aleyrodidae) in Jordan. Turkish Journal Agriculture and Forestry, 34: 225-234.

Bahar, A. A. \& Z. Demirbag, 2007. Isolation of pathogenic bacteria from Oberea linearis (Coleptera: Cerambycidae). Biologia, Bratislava, 62 (1): 13-18.

Bidari, F., M. Shams-Bakhsh \& M. Mehrabadi, 2018. Isolation and characterization of a Serratia marcescens with insecticidal activity from Polyphylla olivieri (Coleoptera: Scarabaeidae). Journal of Applied Entomology, 142: 162-172.

Cakici, F. Ö., I. Ozgen, H. Bolu, Z. Erbas, Z. Demirbag \& I. Demir, 2015. Highly effective bacterial agents against Cimbex quadrimaculatus (Hymenoptera: Cimbicidae): Isolation of bacteria and their insecticidal activities. World Journal of Microbiology and Biotechnology, 31: 59-67.

Cakici, F. O., A. Sevim, Z. Demirbag \& I. Demir, 2014. Investigating internal bacteria of Spodoptera littoralis (Boisd.) (Lepidoptera: Noctuidae) larvae and some Bacillus strains as biocontrol agents. Turkish Journal Agriculture and Forestry, 38: 99-110. 
Davidson, E. W., R. C. Rosell \& D. L. Hendrix, 2000. Culturable bacteria associated with the whitefly, Bemisia argentifolii (Homoptera: Aleyrodidae). Florida Entomologist, 83: 159-171.

Dellaporta, S. L., J. Wood \& J. B. Hicks, 1983. A plant DNA minipreparation: Version II. Plant Molecular Biology Reporter, 1: 19-21.

Demirbag, Z., R. Nalcacioglu, H. Kati, I. Demir, K. Sezen \& O. Ertürk, 2008. Entomopathogens and Biological Control. Esen Offset Printing, Trabzon, 325 pp (in Turkish).

Dillon, R. J. \& V. M. Dillon, 2004. The gut bacteria of insects: Nonpathogenic interactions. Annual Review of Entomology, 49: 71-92.

El-Assal, S. E., N. A. Youssef \& G. A. Amin, 2013. Isolation and identification of locally isolated bacterial strains effective against whitefly Bemisia tabaci. Archives of Agronomy and Soil Science, 59: 779-790.

Eski, A., F. O. Cakici, M. Güllü, H. Muratoglu, Z. Demirbag \& I. Demir, 2015. Identification and pathogenicity of bacteria in the Mediterranean Corn borer Sesamia nonagrioides Lefebvre (Lepidoptera: Noctuidae). Turkish Journal of Biology, 39: 31-48.

Gokce, C., A. Sevim, Z. Demirbag \& I. Demir, 2009. "Identification of bacteria isolated from Rhynchites bacchus L., (Coleoptera: Rhynchitidae) and their effected on the pest, 342". In: Proceedings of III. Plant Protection Congress of Turkey (15-18 July 2009, Van, Turkey), 380 pp.

Grimont, P. A. D., T. A. Jackson, E. Ageron \& M. J. Noonan, 1988. Serratia entomophila sp. nov. associated with amber disease in the New Zealand grass grub Costelytra zealandica. International Journal of Systematic Bacteriology, 38: 1-6.

Henneberry, T. J. \& R. M. Faust, 2008. “Introduction, 1-15." In: Classical Biological Control of Bemisia tabaci in the United States, A Review of Interagency Research and Implementation (Eds. J. Gould, K. Hoelmer \& J. Goolsby). Springer, $343 \mathrm{pp}$.

Ince, I. A., H. Kati, H. Yilmaz, I. Demir \& Z. Demirbag, 2008. Isolation and identification of bacteria from Thaumetopoea pityocampa Den. and Schiff. (Lep., Thaumetopoeidae) and determination of their biocontrol potential. World Journal of Microbiology and Biotechnology, 24: 3005-3015.

Jing, X., A. C. N. Wong, J. M. Chaston, J. Colvin, C. L. Mckenzie \& A. E. Douglas, 2014. The bacterial communities in plant phloem-sap-feeding insects. Molecular Ecology, 23: 1433-1444.

Karman, M., 1971. General Information on Plant Protection Research, Establishment of Trials and Evaluation Principles. Publications of Republic of Turkey Ministry of Agriculture, Plant Protection and Quarantine General Directorate, Bornova-İzmir, $279 \mathrm{pp}$.

Karut, K, M. M. Karaca, I. Doker \& C. Kazak, 2017. Analysis of species, subgroups, and endosymbionts of Bemisia tabaci (Hemiptera: Aleyrodidae) from Southwestern cotton fields in Turkey. Environmental Entomology, 46: 1035-1040.

Lane, D. J., 1991. "16S/23S rRNA sequencing in Nucleic Acid Techniques in Bacterial Systematics, 115-175." In: Modern Microbiological Methods Series (Eds. E. Stackebrandt \& M. Goodfellow). John Wiley \& Sons, New York, 329 pp.

Lelliott, R. A. \& D. E. Stead, 1987. Methods for the Diagnosis of Bacterial Diseases Plants. Blackwell Scientific Publications, Oxford, UK, $216 \mathrm{pp}$.

$\mathrm{Pu}, \mathrm{Y}$. C. \& Y. M. Hou, 2016. Isolation and identification of bacterial strains with insecticidal activities from Rhynchophorus ferrugineus Oliver (Coleoptera: Curculionidae). Journal of Applied Entomology, 140: 617-626.

Roopa, H. K., K. B. Rebijith, R. Asokan, R. Mahmood \& N. K. Krishna Kumar, 2014. Isolation and identification of culturable bacteria from honeydew of whitefly, Bemisia tabaci (G.). Meta Gene, 2: 114-122.

Secil, E. S., A. Sevim, Z. Demirbag \& I. Demir, 2012. Isolation, characterization and virulence of bacteria from Ostrinia nubilalis (Lepidoptera: Pyralidae). Biologia, 67: 767-776.

Sezen, K., 1998. Investigation of Biology, Bacterial Flora and Biological Control Agents of Hazelnut Beetle (Balaninus nucum L.). Karadeniz Technical University Graduate School of Natural and Applied Sciences, Department of Biology, (Unpublished) MSc thesis, Trabzon, $72 \mathrm{pp}$.

Sezen, K. \& Z. Demirbag, 1999. Isolation and insecticidal activity of some bacteria from the hazelnut beetle (Balaninus nucum L.). Applied Entomology and Zoology, 34 (1): 85-89. 
Sezen, K., S. Isci, H. Muratoglu, K. Inan \& Z. Demirbag, 2013. Identification and pathogenicity of bacteria from Gryllotalpa gryllotalpa L. (Orthoptera: Gryllotalpidae). Turkish Journal of Biological Control, 4: 89-108.

Sikorowski, P. P., A. M. Lawrence \& G. D. Inglis, 2001. Effects of Serratia marcescens on rearing of the Tobacco budworm (Lepidoptera: Noctuidae). American Entomologist, 47: 51-60.

Thao, M. L. \& P. Baumann, 2004. Evolutionary relationships of primary prokaryotic endosymbionts of whiteflies and their hosts. Applied and Environmental Microbiology, 70: 3401-3406.

Wunschel, S. C., K. H. Jarman, C. E. Petersen, N. B. Valentine \& K. L. Wahl, 2005. Bacterial analysis by MALDI-TOF mass spectrometry: An inter-laboratory comparison. Journal of American Society for Mass Spectrometry, 16: 456-462.

Yaman, M., O. Ertürk \& I. Aslan, 2010. Isolation of some pathogenic bacteria from the Great spruce bark beetle, Dendroctonus micans and its specific predator, Rhizophagus grandis. Folia Microbiologica, 55: 35-38.

Yu, H., Z. Wang, L. Liu, Y. Xia, Y. Cao \& Y. Yin, 2008. Analysis of the intestinal microflora in Hepialus gonggaensis larvae using 16S rRNA sequences. Current Microbiology, 56: 391-396.

Zhang, C. R., S. Zhang, J. Xia, F. F. Li., W. Q. Xia, S. S. Liu \& X. W. Wang, 2014. The immune strategy and stress response of the Mediterranean species of the Bemisia tabaci complex to an orally delivered bacterial pathogen. Plos one 9 (4): e94477. 